\title{
Laos Economic Structure and Economic Development Policy
}

\author{
Somsanith Sythongbay ${ }^{1, *}$ \\ ${ }^{1}$ School of Economic and Management, Southeast University, Nanjing, Jiangsu 211189, China \\ *Corresponding author. Email: somsanithlaos2222@gmail.com
}

\begin{abstract}
This paper critically explores the Laos' economic structure and economic development policy. The paper highlights that until 1987, Laos was a closed economy defined by district production. After 1987, the economy parades to the external world for FDI and begins to record the economic process. The paper more shows that Laos economic structure is basically mining in Copper, Tin, Gold, Gypsum, Timber; electrical generation; Agricultural process. Trade merchandise grow at $8.92 \%$ compared to the previous years of $3.35 \%$ growth of electricity and power offer, $2.75 \%$ growth of producing, $2.35 \%$ growth of construction and $0.68 \%$ growth of mining and production. The recently revised economic development policy favors FDI and Laos can before long gain economic momentum.
\end{abstract}

Keywords : Economic structure, Economic growth, Economic development policy, Foreign Direct Investment (FDI).

\section{INTRODUCTION}

Many countries of the world over square measure keenly operating towards restructuring their economic policies to form a landscape for an economic boom. This is often thus because the economic structure of any country includes a profound influence on the economic propensity and labor productivity of that economy. However it is the price mentioning that what constitutes $\mathrm{AN}$ economy's structure varies from one country/region to a different because of variations in geographical locations and adoption of various economic policies that ultimately form the structure of a selected economy. To this impact, the economic structure determines however, the resources during a country square measure divided and it is major implications on what sorts of jobs or product square measure obtainable. It is a serious impact additionally on the countries' customary of living. In other words, the economic structure of an economy could perform of the addition of all the various economic activities within the geopolitical boundaries of that space (Aren Van Schalkwyk).

According to the Structure Conduct Performance (SC-P) model by Edward Chamberlin and Joan Robinson, market structure is one different vital dimension of the economic structure, as a result of that it helps in determinant, the quantity and size of corporations in an economy, trade concentration, technological and value conditions, demand conditions. Simple entry and exit within the economy of these square measures essential in prediction labor productivity and ultimately growth in an economy.

Most developing countries like Laos have unstable market structures ensuing from the implementation of weak economic development policies. While Conduct deals abundant with the value of products and services aboard analysis and Development (R\&D) Performance accrue to the welfare ensuing from numerous economic activities. This paper makes an attempt to assess Laos' economic structure and economic development policy supported a literary criticism of secondary knowledge. Laos could be an inland country placed in geographical areas fringed by the Union of Burma, Cambodia, China, Thailand, and Vietnam. It is a population of $6,769,727$ with an annual increase rate of 1.847 and Age Dependence quantitative relation of 63.849 you look after the working-age population as of 2013 statistics. The government system could be the Communist staterun. The head of the state is the President and the leader of the presidency is the Prime Minister. Laos includes an economic system within that the government have enforced regular economic and corporate improvements to ease up its local marketplaces. She could be the member of the Association of Southeast Asian Nations (ASEAN) (American Embassy 2005). Therefore, the full paper is organize as follows; when the introduction, 
a quick review of literature shall be provided. Thereafter, a discussion of findings and so a conclusion shall be drawn.

\section{LITERATURE REVIEW}

The Laos' government is one in every of the little outstanding unilateral communist states. It started distributive management and inspiring non-public enterprise in 1986 beneath this New Economic Mechanism 'NEM'. The results, ranging from a very small base, were placing growth averaged 6 June 1944 p.a. from 1988-2008 excluding the transitory drop affected by Asian monetary shortages that started in 1997. Laos' growth topped seven-membered p.a. throughout 2008-13. In spite of the high rate, Laos rests a rustic with the under construction groundwork, notably in rural zones. It is a simple, however rising, road structure, and restricted exterior and interior landline telecommunications. Electricity is out there in eighty-three you look after that country. The economy of Laos is drastically smit by capital-concentrated resource exports. The proletariat still depends on agriculture, conquered by rice farming in the coastal regions that accounts for concerning twenty-fifth of gross domestic product and seventy-three of the entire employment. The economic process has lessened the official impoverishment rates from forty-sixth in the year 1992 to twenty-sixth in the year 2010 (Lao National Chamber of the Commerce and trade, 2015).

Recent studies conjointly acknowledge that the economy has profited from rich foreign direct investment (FDI) in the hydropower, copper and gold mining, logging, and the construction although some come in the industries have drawn blame for his or her environmental effects. Laos extended traditional Trade Relations standing with U.S.A. in 2004 and made application for the Generalized System of Preferences trade edges in the year 2013 when being admitted to the planet Trade Organization (WTO) formerly within the time.

Some economic reports co-jointly show that Laos is within the method of implementing an excise structure. Streamlined investment processes and enlarged bank credits for tiny farmers and little tycoons are probable to boost Laos' economic prospects (Annual Economic Report 2013). The government seems loyal to nurturing the country's outline in the midst of investors, however, underwent through a commercial enterprise shortages in the year 2013 caused by the public region income will increase, commercial enterprise direction, and revenue shortfalls. Economic Development reports from the planet Bank have confirmed that the goal of Laos of advancing from the UN Development Program's list of the developing countries by the year 2020 is accomplishable. Therefore, the nation is inclined to come in the Association of the Southeast Asian Nations
Economic Community in 2015 (Lao National Chamber of the Commerce and trade, 2015). Though this could mirror truth, there want for the government of Laos to figure for it by making a causative economic roadmap for domestic investment.

Other studies on Laos indicate that the economy of Laos is defined by a resilient growth path, compelled by massive investments and personal consumption. More so, buoyant Gross Domestic Product (GDP) growth in past few years $(+7.8 \%$ 10-year average) has been mostly drive by the magnified share and speedily emergent local needs. However, issues above the warming of the economy have developed since the fast economic process has been shoot by commercial enterprise growth and fast credit growth. Growth is one in every smallest amount unstable within the area. GDP growth is about to lose pace to $+7.4 \%$ in the year 2014 and $+7.0 \%$ in the year 2015, on the rear of lesser growth in Laos' 2 key partners: China (25\% of the exports) and the Kingdom of Thailand (39\% of the exports). it's anticipated thus that, the Chinese yearning for the metals and different resources that drove Laos' fast export growth and huge investments in the sectors is additionally affordable going forward (The Seventh Five-year National SocioEconomic Development arrange 2011). Inflationary forces were raised $(+6.7 \%$ year/year in the December 2013) however these reduced speed severely through the year 2014 , getting $+3.05 \%$ in October 2014 . It ought to an average of $+4.3 \%$ in the year 2014 and develop to some extent to $+5.0 \%$ in the year 2015 . Laos' resilient growth has been in the middle of a fast increase in credit $(+32.1 \%$ year/year in the September 2013), adding the chance of warming.

It somewhat over-involved in the year $2014(+20.1 \%$ in Gregorian calendar month 2014). All authorities square measure imposing industrial banks to use Basel two, to lift capital, and enhance the supervising of banking industry. Non-performing loans square measure comparatively less, at $2.1 \%$ in Gregorian calendar month 2014

The weaker business atmosphere stays an economic burden and limitation all the same recent enhancements, notably regarding the supply of credit and protective minority investors, Laos continues to be graded 148 out of the 189 economies by the planet Bank's 2015 Doing Business Survey (World Bank, 2015). Laos positions at 189 , in the last place, concerning financial condition resolution. In addition to it, the planet Bank Institute's Worldwide Governance Indicators 2013 survey mark severe issues with relevance rule of the law and management of dishonesty (graded under the typical of East Asia and the Pacific region).

Further reports also show that substructure is pitiable in Laos, restraining the export potential for the blockedin economy. Laos is listed 131 (out of the 160 countries) in relation of the International Logistics act in the World 
Bank study. However, it is being expect to recover by moving ahead with the increase infrastructure investment back up by the local people and by the outside investors.

According to the Annual Economic Report 2013, public finances have declined speedily but the monetary alliance is in its way. Statistics further indicate that, from the year 2012 to the year 2013, this monetary balance worsened gradually, from $-1.2 \%$ in the monetary year $2011-12$ to $-5.6 \%$ in the year 2012-13. Government expenses have pitched from $24.8 \%$ of the GDP to $29.9 \%$ in the year 2012-13 because of (1) growth in the public zone incomes, (2) and greater capital expenditure while income growth has reduced with the lower profits from the mining sector.

By taking into consideration the financial pressures, innovative steps were launch by the government and improvised budget rules to target in lessening the fiscal shortages. The current monetary alliance should assist having the monetary deficit to $-4.6 \%$ of the GDP in the year 2013-14 and $-4.0 \%$ in the year 2014-15. Nearly $60 \%$ of the GDP is usually, covered by the public debt and will remain similar in upcoming years too. Nearly $75 \%$ public debt is finance by external resources. Central Bank finance more than half of the overall local and domestic debt for the local government out of the budget infrastructure developments. The Lao National Chamber of Commerce and Industry (2015) states that huge import development led to a severe descent of Laos' exterior spot. In the year 2012, nearly $80 \%$ of the exports were focus in the direction of Thailand, China, and the Vietnam. One third of the exports consist of the non-ferrous and the ferrous metals, mainly exported to the China. With the huge hydraulic capitals, the country trades power to the neighboring nations (nearly $15 \%$ of the exports in the year 2012). Laos linked with the ASEAN in the year 1997 and is now a part of World Trade Organization (WTO) since the start of the year 2013. Therefore, the final compliance with WTO should assist the country to expand the export structure. Present account statistics are tricky and vary huge between the causes relying on the dimensions of exterior trade statistics.

According to the Asian Development Bank statistics, Laos' current account shortage fell dramatically from $+2.0 \%$ in the year 2011 to $-4.5 \%$ of GDP in the year 2012 as mentioned (1) enhanced domestic demand (in the year 2012 , the imports risen by $+37.1 \%$ while the exports risen by only $+6.5 \%$ ), (2) the reducing mineral prices and (3) the growing monetary shortage. We usually expect that it will lower to nearly $-3.3 \%$ of the GDP in the year 2014. Foreign Direct Investment (FDI) constitutes nearly $54 \%$ of the current deficit. They have grown drastically in past few years, especially in the hydropower zone. Laos' outer debt is assume to constitute nearly $65.6 \%$ of the GDP in the year 2014 .
However, a big share is dependent on the concessional debt.

In Thai market, Laos sold its very first sovereign bond in the year 2013 and then later on the other two bonds in the year 2014. This money is allowed to float within $+/-5 \%$ of the band. The solid guarantee assisted the nation to slowly, come to be a lesser amount of dollarize. The dollar rate, as dignified by foreign currency credits as a ratio of wider money, reduced from $76 \%$ in the year 2000 to nearly $40 \%$ in the year 2013 . Foreign exchange assets are unstable, wrapping lower than the suggested 3 months of the imports. In March 2014, reserves covered approximately 2 months of imports (www.eulerhermes.com). Therefore, already we can see that there is more to be done if the Laos economy was to gain an economic impetus.

\section{LAOS ECONOMIC STRUCTURE AND ECONOMIC DEVELOPMENT POLICY: DISCUSSION}

\subsection{Economic Composition}

The economy of Laos is drastically keen on capitalconcentrated natural resources exports. In terms of international trade, exports of goods and facilities (percentage of the GDP) is 37.22 percent compared to the imports of goods and facilities (percentage of the GDP) of $46.15 \%$. Key prime industries are mining; Timber; electricity; Agricultural development. Trade product are calculable to grow by a slower pace as $8.92 \%$ compared to the previous years as a contribution of $3.35 \%$ growth of electricity, and power provide $2.75 \%$ growth production, $2.35 \%$ growth of construction and $0.68 \%$ growth of mining and production reach $11,339.39$ billion that accounts for $28.60 \%$ of real GDP (Lao Statistics Bureau 2013). However, in sum, despite the drawback risk from declining in artifact costs in the international market, with the high potential of electricity and water system, LED growth remains high.

The GDP of economy of Laos is structured as follows; GDP, Palatopharyngoplasty (current international \$) was at $\$ 33$ billion as of 2013. GDP rate of growth (annual \%) was at $8.518 \%$ as of 2013. GDP Per Capita, Palatopharyngoplasty (current international $\$$ ) was positioned at $\$ 4,822$ in 2013 . More so, the country's GDP was hierarchic $112 / 192$ as of 2013 . The growth rate of the country has been lameness with fluctuations from $78 \%$ in 2008 to $7.50 \%$ in 2009 ; from $13 \%$ in 2010 to $8.04 \%$ in 2011; from $7.93 \%$ in 2012 to $7.95 \%$ in 2013 (Laos Statistics Bureau, Ministry of coming up with and Investment, 2013).

This implies a sensible however unstable economy that might consume away capitalist confidence. A stable rate of growth is not solely instrumental in coming up with however conjointly in statement investment profit. In terms of international trade, the economy of Laos is a 
structure in such how that, imports of products and services were then as of 2013 valued at $\$ 5,188$ million. Meanwhile, exports of products and services were valued at $\$ 4,184$ million within the same year 2013. His suggests that the country truly imports a lot of products and services than it exports and this will result in a deterioration within the negative balance of payments and worsen the economy if not well checked. Meanwhile, total merchandise trade as a share of GDP was $46.997 \%$ in 2013 and so suggesting that trade incorporates a larger role to play within the economy of Laos for its economic development. Likewise, Foreign Direct Investment (FDI), internet inflows were at \$427 million in 2013 whereas business service exports were at $\$ 552,939,912$ in 2012 (Annual Economic Report, 2013).

\subsection{Economic Process}

GDP is Associate in Nursing and other reliable indicator of Associate in Nursing economy's productivity mirrored in figures because the total price of all products and services created in an economy over the amount of one year expressed in financial terms. Laos GDP has on the face of it remained comparatively stable in a very few years ago when putting next to different economies exposed to similar international economic weather conditions. This can be not implicational the very fact that Laos is proof against international economic challenges however that Laos has within the recent past recorded large enhancements in its domestic production through exports on foreign markets within the aftermath of its economic relief. Economic knowledge bases from the planet Bank cluster (2015) shows records that, throughout the 2008/2009 international depression, each World GDP which of the Latin America and Caribbean developing economies had recorded $-1.6 \%$ within the aftermath of 2009. Likewise, Europe and Central Asian developing economies had recorded $-4.8 \%$ GDP. However, Laos GDP was $7.5 \%$ within the same year. The planet Bank more indicates that, since then, Laos has with success been recording a rise in GDP from 2009 (7.5\%) to 2013 $(8.5 \%)$ as shown within the figure below.

This gradual stability within the GDP over the years may be attribute to the fact that the economy of Laos has discovered sound investments in mining, energy, manufacturing, agriculture, and construction. Also a number of exports in timber, energy, metals because the rejuvenated trade agreements and economic zones have had a profound influence on overall productivity.

\subsection{Structural Weaknesses Limit Economic Development Potential}

The Laos economy may be love for its robust, resilient, and stable GDP growth, which ends up from its issue endowment productivity. More so, the country's massive natural resources, namely; mining, agriculture, and water, do have an Associate in Nursing economic propensity of boosting exports that earns the country forex for its domestic currency power.

Within recent decades thus far, there has been increased (Foreign Direct Investment-FDI inflows within the country (Lao National Chamber of Commerce and trade, 2013). This has resulted in infrastructure development, technological transfer, and employment creation for the individuals of Laos. Nonetheless, the economy of Laos is additionally defined with a weak economic structure that produces the economy fail to record property development. The business atmosphere is additionally terribly fragile. There are deprived communal funds with a pointy worsening of business enterprise deficit in the recent years. The amount of outer debt is quite out of the question. There are low interchange reserves that make the economy incompetent. Problems to try to with transparency are of nice concern within the economy of Laos so deteriorating the already weaker structures. The immoderateness in credit growth and also the risk of warming all have resulted in fruitlessness (Annual Economic Report 2013).

In these days, the government of Lao is progressing in the direction of enlightening the exchange and venture rules to empower the FDI and exchange the nation. The Laos is investigating the rules of an assortment of fair-arranged nations nearby the globe. In these days, it has more than forty rules and regulations and many declarations and guidelines. Since the year 1989, the vast majority of announcements and guidelines are draft for example the Verdict on freedom of FDI have included by numerous Decrees, Rules and Judgements. The Law on FDI in the year 1994, the Decree No. 46/pm in the year 2001 regarding the venture guideline, the choice No.13/pm regarding the perfection of standards for thought and endorsement methodology of the FDI (Flipse, Doran and the Lê, 2002).

\subsection{Speculation Promotion Policy}

Laos has the generous speculation systems in the locale. Since the year 1994, unfamiliar venture rule in Laos are usually, guided by Investment Promotion Acts, which are rules on the Promotion and Management of Foreign Investment (2004), Law on the Domestic speculation (1995), Business law (1994), Customs law (1994) and the most important Tax law (1998). Different rules administering unfamiliar speculation incorporate the mining law, the land law and the power law (Department of the Domestic and the Foreign Investment of Lao PDR (DDFIL), 2003). Business law and the property law are being, created. Unfamiliar undertakings or unfamiliar speculators usually cannot 
possess plot as expressed in the Article 25 of the Use of Land: "It is disallowed for an Overseas Investor, an unfamiliar venture endeavor or a far off public to be permitted to claim property in Lao PDR. Outsiders can rent land straightforwardly from the Lao PDR or a Lao public under the particulars of a land rent understanding made as per the property rules. All the property has a place with the Lao public network" (DDFIL, 2001, pg.no. 12).

As indicated by DDFIL (2003), FDI rule of 1994 portrays the strategy for unfamiliar interest in Laos. This law is likewise intend to draw in industrialist elegance undertaking and comprises generous arrangements for the return of benefits and inclusion of unfamiliar value in Laos' organizations. It plots the territories wherein unfamiliar venture is supported and those regions where unfamiliar speculation is not permitted. Unfamiliar Investment rules in Laos were usually, built below the Investment Promotion Act in the year 1988 and has made the Department of Domestic and the Foreign Investment of Lao to oversee venture authorizing and advancement and depart speculation guidelines. The rule sets out the rapports and states of interest in the Laos. Inside one whole year of the presentation of the unfamiliar venture law, the nation got nearly 124 applications for speculation activities, and 60 undertakings were endorse. In any case, the legislature was worried that a few activities affirmed in the mid of 1990 were not reliable with the administration improvement objectives. For example, many proposed ventures included the Thai interests in ranger service, which the government of Lao measured as supplementary unfair than profitable, and not to trade. From that point forward, the Lao government concentrated on ventures, which include present day innovation move to the Laos (Brahm and the Macpherson, 1990, pg.no.23).

The administration of Laos has found a way to improve the venture atmosphere in the nation as of late. The legislature has changed its constitution including motivating forces for different parts and speculation zones and refreshed on venture guidelines, decentralized speculation and endorsement measure at focal and commonplace levels (World Bank Group, 2005). The innovative declaration gave on $23^{\text {rd }}$ of April 2003, characterizes the obligations of important priests and specialists at focal and neighborhood levels (DDFIL, year 2003). Moreover, the venture rule sets innovative arrangement motivations comprising the advanced zone regions. The enactment abbreviates the speculation application strategies and handling time. It has decreased the duration in the speculation permit endorsement from 60 days to under 50 days for advanced parts, 25 working days for advanced segments with the certain limitations, and 45 days for enormous scope tasks undertakings identified with common assets (WBG, year 2005).
The year 1994 venture advancement guideline was overhaul and given by the Governmental Decree No. 11/NA on 22 October 2004. The New Decree is to supplant the rule of FDI of the year 1994. In these days, unfamiliar venture law in the Laos depends on the new and innovative Law on Promotion of the Foreign Investment (2004), Business law (1994), Customs Law (1994), and the most important Tax Law (1995). The overhauled rule on Promotion of the Foreign Investment (2004) happened on January 14, 2005 (United Nations, year 2005, pg.no.36). The pronouncement subtle ties venture methods, innovative obligations and motivators. The announcement additionally diminishes venture time period. It additionally sets out the updated charge motivations to unfamiliar speculators as indicated by advanced exercises and advancement. One key highlight of the updated FDI rule is that Lao government is leaving on the basic change on decentralization of unfamiliar speculation the executives' power; permitting neighborhood specialists to pull in venture to their districts. Likewise, the reconsidered law diagrams the types of worthy unfamiliar venture and the rights, advantages and commitments of each sort of speculation. In any case, the law rejects roundabout speculation, for example, credits, help and general purchasing and selling of products.

\subsection{Foreign Investment Policy Flexibility}

One major benefit is that Laos has terminated its neighbors and that foreign companies could completely possess and function a trade in any supported zones (American Embassy 2005:20). However, overseas investors' area units constrained from partaking inbound business activities while not permitted by the government of Lao. The constrained business actions embody manipulation, accounting, travel, significant automobile or equipment operation, and rice gardening. These limitations area unit supposed to shield the stateowned enterprises (SOEs). On paper, the foreigner's area unit involved in most of those actions. Refugees' area unit is often active in broadcastings. In distinction, in the Vietnam and in China, there area's unit limitations on the activities during which the entire foreign closely held asset enterprise will interact. On entire foreign closely held enterprises below the policy of People's Republic of the China (PRC), initiatives could solely be, proven if they interact in skill transfer and export major part of their merchandise.

In the Laos, Associate in Nursing and solely foreign closely held enterprise will be established, in spite of whether or not those enterprises area unit reputable with foreign or native share (Brahm and the Macpherson, year 1990, pg.no.36). 


\subsection{Foreign Possession}

Their area unit bound restrictions regarding investment approval during a venture project. The DDFIL considers foreign investments on an individual basis of the proportion of foreign possession inbound sectors. The foreign investment law of 2004 permissible 100 percent foreign possession all told sectors. The investment comes involving mineral exploration and mining, and the wood process area unit subject to government agreement and process. A far off partner should contribute a minimum of thirty percent of the number of capital. Prohibited activities involving foreign investments embody activities damaging to the atmosphere, health, or national culture, (DDFIL, 2004). Consistent with the DDFIL (2003), foreign firms' area unit granted special privileges that embody a discount or exemption from tariff rate owing to the big size of their investments.

The bulk of infrastructure and services in Laos like electricity, water, and domestic traveling area unit provided by State closely held Enterprises (SOEs), though in telecommunications personal suppliers are delivering these services. The foremost recent section of State reform began once the govt. committed to attracting FDI in Laos. The SOEs manages a variety of utility sectors. These embody Electricite Du Laos, Enterprise of Telecommunications Lao, Lao Airlines, Lao State Fuel Company and Capital installation State Enterprise, Nam father Lao (Nam father State-Owned Enterprises (NPSEs) in Bokeo, Bolikhamxay, Champasak, Huaphanh, Luang Phabang, Oudomxay, Savannakhet, Sekong, Laotian capital Province.And Xieng Khouang; 2 NPSEs (Luang Namtha and Nam father Lao), Lao still Co. Ltd, Lao Soft. Drink Co. Ltd, Lao Insurance Co. Ltd, Lao Tobacco Co. Ltd, and Lane Xang building Enterprise.

The govt. of Laos is additionally restructuring four SOEs. They are Lane Xang Phatthana, skeletal muscle Visahakit Sanong Vatthou Technique, skeletal muscle Visahakit Konchak Kasikam, and Borisath Phalithaphanh Beton Lao. The Restructuring Unit within the Business Promotion workplace has been appoint to supervise the preparation of restructuring plans (WBG, 2006). The revenue of the eleven largest (SOEs) (including joint ventures and excluding banks) accounted for quite seventy percent of all SOEs revenues in 2004. Among these, revenues of 5 SOEs absolutely closely-held by the government of Lao PDR accounted for concerning forty-two percent, revenues of six venture SOEs for around thirty-one percent, revenues of others (more than a hundred and twenty SOEs) comprised but thirty percent (WBG, 2006).

The Lao telecommunication sector has been growing quickly. Ten years ago, the world was dominate primarily by one player Lao telecommunication
Company. Now, there area's unit include five firms (state-owned, joint venture, and private) that give telecommunications services in Lao PDR. A Thai Sky Telecomm Company entry in 2006 is that the most upto-date addition to the world. The quantity of web service suppliers (ISP) has magnified from 2 companies in the 1999 s to concerning six players in early 2000 and currently quite eight ISPs, like STEA, ETL web, Lao telecommunication, Champalao web, Lanexang web and Sky telecommunication, KPL, (WBG, 2006). There area's unit include four authorized enterprises to produce mounted and mobile telecommunications in Laos, with all four providing mobile phones however solely three providing mounted lines. All of them have some government possession. The enterprise's area unit as follows: Lao Telecommunications Co Ltd (LTC holding is the government of Lao PDR (GOL) fifty-one, Shinawatra 49\%); Enterprise des Telecommunications Lao (ETL, GOL 100\%); Lao Asia telecommunication (LAT, Ministry of Defense 100\%); Millicom International Cellular militia (GOL twenty-second, Millicom 78\%). The primary 3 give the mounted line, mobile and alternative services, whereas the last one provides mobile and alternative services (WBG, 2006). The entry of Millicom, the big holding by Shin corporation, the operations of Planet, and also the prevalence of phonation web Protocol (VoIP) operators show that personal investors area unit willing to take a position in Laos below this policy regime.

However, such investment remains restricted to activities in Laotian capital (WBG, 2006). Meanwhile, the banking sector of Laos is dominated by State closely-held Banks (SOBs) that area unit beginning to become market homeward-bound. Personal domestic banks play a little role and foreign banks have created a very little impact within the context of market share the little size of the personal sector and foreign banks is attributed to the role of the govt. in several segments of the economy (directly or indirectly). Banque Pour Le Commerce Extérieur Lao retains a dominant position, accounting for concerning $1 / 2$ total deposits and loans within the system. The Lao Development Bank, ensuing from the merger of 2 smaller SOBs - Lao Bank and Lane Xang Bank is smaller.

\subsection{Assessment and Duty Incentives in Special Promotion Zones (SEZ)}

From the time Laos actualized its open entryway strategy in 1988, there has been a declining unfamiliar venture levels in territories outside Vientiane. In the previous ten years, charge and non-charge motivating forces were not elevated significantly to pull in unfamiliar venture into the SEZs.

Along these lines, there was an absence of straightforwardness in the advancement of unfamiliar interest in Laos, which has brought about declining 
unfamiliar speculation levels in provincial territories. On April 13 2003, the legislature of Laos acquainted obligation impetuses with encourage financial specialists under the nation's first foundation of SEZs planned for pulling in FDI and ability. The significance of the SEZs is to build up the outskirt territories with China, Vietnam, Cambodia, Myanmar and Thailand. The SEZ is roughly $500 \mathrm{~km}$ south of Vientiane and situated in the area of Savannakhet along the East-West Economic Corridor (EWEC) connecting Myanmar, Thailand, Laos and Vietnam. One of the administration strategies in elevating FDI to the SEZs is to support unfamiliar ventures in which to create frameworks and award more special activities. The legislature is actualizing this strategy in perceiving the need to pull in unfamiliar speculations to regions outside Vientiane to improve the financial conditions, along these lines improving the way of life of individuals in provincial territories.

The impact of the new declaration should help with making openings for work in the provincial regions, produce unfamiliar trade income and construct neighborhood foundations for financial government assistance of the individuals of Laos. As indicated by Article 18 of the updated law (2004), unfamiliar financial specialists contributing inside the advanced exercises and zones are qualified for the accompanying duty impetuses:

Zone 1: Investments in Zone 1 will be qualified for a benefit charge exception for a long time and from this point will be liable to benefit charge at the pace of $(10 \%)$.

Zone 2: Investments in Zone 2 will be qualified for a benefit charge exclusion for a long time, and from this point will be dependent upon a decreased benefit charge pace of half of fifteen percent $(15 \%)$ for a long time and from there on a benefit charge pace of fifteen percent $(15 \%)$.

Zone 3: Investments in Zone 3 will be qualified for a benefit charge exception for a long time and from this point will be dependent upon a diminished benefit charge pace of half of $20 \%$ for a long time and from that point a benefit charge pace of $(20 \%)$. Under this law, benefit charge exception begins from the date of the unfamiliar venture's initiation of business tasks.

For some tree manor exercises, benefit charge exception initiates from the date the endeavor begins making a benefit. When the benefit charge exclusion period is finished, the unfamiliar venture undertaking will pay benefit charge as per the laws and guidelines. Notwithstanding the above motivators, unfamiliar financial specialists are qualified for the accompanying impetuses:

(1) During the assessment exclusion period and during the expense decrease period, the endeavor is qualified for an exception of least duty.

(2) The benefit utilized for the extension of authorized business exercises will be exclude from benefit charge during the bookkeeping year.

(3) Exemption of import obligations and duties on gear, save parts, vehicles legitimately utilized for creation, crude materials, which don't exist locally or exist however are inadequate, semi-completed items imported for assembling or for preparing with the end goal of fare.

(4) Exemption of fare obligation on trade items. Another alluring component of this law is that crude materials and semi-completed items imported for assembling or gathering for import replacement will be excluded from import obligations and burdens or will be liable to diminished paces of import obligations and assessments. SEZs, Industrial Zones, Border Trade zones and other explicit monetary zones will observe the laws and guidelines of such explicit zones.

\subsection{Venture Constraints}

Laos is confront with testing venture condition because of the absence of muddled guidelines, blend of Chinese and Vietnamese law styles, wasteful framework and administrations in the monetary administrations. FDI isn't precisely revealed by the Lao government (the official figures show affirmed, not genuine ventures), and genuine speculation levels are in this manner hard to gauge. The genuine degree of unfamiliar speculation is likely higher than the official assessments. The Law on the Promotion and Management of Foreign Investment of Laos is extremely essential. Laos' legitimate framework needs consistency and executing guidelines. For instance, import obligations and duty exclusions, probably ensured to unfamiliar financial specialists, are not reflected in either customs or expense law. Multilateral organizations and private specialists are helping the Lao government executing guidelines, including the FDI law. Notwithstanding, apparently organization regularly blocks this cycle. What's more, global benefactors are helping Laos' promotion to the World Trade Organization (WTO). This likewise helps business law of Laos into congruity with WTO norms, and may advance more noteworthy straightforwardness and consistency in the lawful and administrative of FDI law in Laos (American Embassy, 2005, p.17-20).

\subsection{Suggested changes to the present Economic Investment Policy}

Government authorities' area unit considering approaches to decrease the government officials' obstructions that unknown speculators face once applying to place resources into Laos. The 
administration is inspecting approaches to enhance speculation laws, concentrating on venture impetuses, for instance, extraordinary advantages, charge waivers and assortment and customs ways, fast and rearranging application techniques (Pansivongsay, capital of Laos Times, 28/01/2005). Virtually definitely, the administration could allow unknown speculators to urge the same treatment of assessment and levy motivations as social unit monetary specialists. Below this framework, interests in "advanced enterprises" would get assessment and obligation decrease motivations, however, interests in numerous divisions would pay the normal company profit charge, turnover expense, and obligation rates (DDFIL, 2003).

On the off probability that once Laos turns into private from the world organization all things thought of, unknown speculators get the same treatment of duty and tax as native monetary specialists. The representative superintendent of the design and Co-activity Department of Savannakhet, Siphon Nantharat, remarks' "Laos is off guard to the Kingdom of Thailand and Vietnam on the off probability that it depends on its current speculation laws. These laws do not make sure the nation in such things as expense assortment" (Vientiane Times, 10 March 2002). Laos is creating speculation less complicated by creating methods faster, tolerating archives for getting ready every Friday. As per the capital of Laos, Deputy civil authority. Dr. Sinlavong Khoutphaythone". If the task desires Government authorization, the monetary specialist can get a solution within seven days, faster than the sixty days determined in law. For ventures value up to US\$5 million, the capital of Laos is enabled to decide on the selection and can reply within fourteen days. He enclosed that this facilitating has been in activity since the start of the year" (Pansivongsay, capital of Laos Times, 28/01/2005).

\section{CONCLUSION}

To wrap up, this journal endowed to examine Laos economic structure and economic development policy. It has been, made mention that, since commencing the economic improvement progression in the year 1986 beneath the New Economic Mechanism "NEM" the economy of Lao has moved from a centralized, intended economy in the direction of an open, generous marketbased system. "Open-door" policies headed for international market have been, improvised to support and fascinate FDI. These alterations have significantly made positive conditions for economic growth. Therefore, there is need for Laos to learn from the Asian Tigers who did not only open up their economies but also were export-oriented economies from domestic production.

\section{ACKNOWLEDGMENT}

This work was supported by National Natural Science Foundation of China (61303022), Natural Science Major Project of Jiangsu Higher Education Institutions (17KJA520002), and Nanjing Scientific \& Technological Innovation Project for Outstanding Overseas Returnees.

\section{REFERENCES}

[1] The World Bank, Yearly Economic Report, 2013.

[2] The American Embassy, A rustic business Guide for U.S. Business, Vientiane, Laos PDR, 2005.

[3] The Brahm, .., \& The Macpherson, N. Interest within Lao People's Democratic Republic. In Hong Kong: Longman cluster, 1990, p. 36.

[4] Implementation of Law on Promotion and the Management of Foreign interest within Lao PDR. The Division of Domestic and Foreign Investment of the Lao PDR, Council for designing and the CoOperation. PM. Announcement of Prime Minister No.64, Official Version., Initial Edition, 2001.

[5] The World Bank cluster, Vientiane, 2015. http://data.worldbank.org/pointer/gotto 2015/05/15

[6] DDFIL, Implementation of Law on Promotion and the Management of Foreign interest within Lao PDR. The Division of Domestic and Foreign Investment of the Lao PDR, Council for designing and the Co-Operation, 2001.

[7] Financial and the Social Commission for the Asia and for the Pacific. (n.d.). Retrieved from: http://www.unescap.org/tid/distribution/tipub2390. asp

[8] Flipse, Doran, \& Lê. The Law Report. Vientiane, Laos PDR, 2002. http://www.mekongexpress.com/laos/general/law2. $\underline{\mathrm{htm}}$

[9] Joined Nations, Traders' Manual for the Least Developed Countries: The Lao People's Democratic Republic. Laos PDR.

Lao National Chamber of Commerce and Industry, (2005).

[10] Pansivongsay, M.The Capital of Laos Lures a lot of Investment. Capital of Laos Times, 2005.

[11] Sisombat, S. The Determinants of unknown direct interest in the Laos: The discourse investigation of the Associate in the Nursing Australian mining organization. Victoria Universty, The Victoria graduate school of Business. Melbourne: 
Unpublished D.B.A Theory, 2007.

[12] SSSEZA. The Division of Foreign Affairs and the Trade. The East Asia Analytical Unit. Canberra: Australian Government Publishing Service, 1997.

[13] SSSEZA, Division of Domestic and the Foreign Investment of the Lao PDR, 2003. http://www.invest.laopdr.org

[14] SSSEZA. The Trade and the repair Hub of the East and the West Economic passageway. Handout, SSSEZA, The Savan-Seno Special Economic Zones Authority, Vientiane, (2003).

[15] The Government of Laos PDR. (n.d.). Seventh Five-year National Socio and Economic Development set up . Open Development Laos, 2011-2015.
[16] The Lao PDR Economic Monitor. (n.d.). The World Bank cluster . The World Bank, Vientiane, (2005).

[17] The U.S. Government Trade Department. 2005. http://www.ustr.gov/resources/Document_Library/ Reports_Publications/2006/2006_NTE_Report/asse t_upload file204 9256.pdf

[18] The unknown Direct Investment in the Lao PDR. The Vientiane Times, 2002. http:www.vientianetimes.org.la

[19] The World Economic Outlook. International fund. Retrieved from IMF, 2014.

[20] WFP. (n.d.). The LAOS PDR nation Strategy. The World Food Program (WFP), 2011-2015. 